\title{
PENGETAHUAN DASAR DESAIN TIGA DIMENSI SEBAGAI CARA MAHASISWA DESAIN UNTUK BERPIKIR BENTUK RUANG DAN VOLUME
}

\author{
R. Tosan Tri Putro \\ Program Studi Desain Produk, Fakultas Arsitektur dan Desain, Universitas Kristen Duta Wacana, \\ Jl. dr. Wahidin Sudirohusodo No. 5-25, Yogyakarta \\ Email: tosan1991@yahoo.com
}

\begin{abstract}
Abstrak
Kesadaran mengamati bentuk dan ruang pada sebuah obyek benda, baik berukuran besar maupun kecil adalah kepekaan yang menjadi bekal seorang perancang obyek-obyek benda tiga dimensi. Sebuah bentuk produk tercipta dengan penuh kesadaran oleh perancangnya, bukan dengan sendirinya muncul dengan intuisi. Selain fungsi pada obyek rancangan, dalam sebuah proses desain ada tahap styling, nilai estetis secara visual, bentuk yang mengikuti fungsi atau bentuk yang mengikuti material. Nilai estetik pada sebuah produk rancangan yang tidak lepas dari kemampuan sang perancang dengan pengalaman visualnya. Kemampuan dan kepekaaan dalam mengamati dan mencipta bentuk visual yang estetik semestinya ditanamkan sejak seseorang menyatakan dirinya ingin menjadi seorang perancang atau desainer dalam hal ini siswa/ mahasiswa. Bidang seperti arsitektur, tata kota, kawasan, interior dan juga desain produk tertuntut kemampuannya terhadap kepekaan mangamati dan merancang sebuah ruang, volume dan bentuk. Penelitian ini berdasarkan pengamatan pada sekelompok mahasiswa desain dan studi literatur. Berdasarkan pengamatan dalam beberapa waktu, kemampuan berpikir ruang dan bentuk yang dimiliki oleh setiap orang berbeda, demikian juga kemampuan mencipta nilai estetik pada sebuah rancangan. Setiap orang mempunyai daya serap dan daya cipta yang berbeda.
\end{abstract}

Kata kunci: desain dasar, tiga dimensi, ruang, volume, estetis.

\begin{abstract}
Title: Three Dimensional Basic Design Knowledge as Thinking Tools for Understanding the Shape, Space and Volume

The consciousness of observing the shape and space of an object, whether large or small, is the sensitivity that becomes a designer of three-dimensional objects. A product form is created with full awareness by the designer, not by itself appearing. In addition to the function of the design object, in a design process there is a styling stage, aesthetic value visually, a form that follows the function or shape that follows the material. Aesthetic value in a design product that can not be separated from the ability of the designer with visual experience. The ability and sensitivity to observe and create an aesthetic visual form should be instilled since someone declares himself to be a designer or planner. Design areas such as architecture, interior, urban design, area and also design product are demanded for their ability to sensitize observing and design a space, volume and shape. This study is based on observations on a group of design students and literature studies. Based on observations over time, the spatial thinking capacity of each person is different, as is the ability to create an aesthetic value in a design. Everyone has different absorbtive power and creativity
\end{abstract}

Keywords: basic design, three dimensions, space, volume, aesthetics. 


\section{Pendahuluan}

Menurut Rowena Reed Kostellow, tidaklah cukup waktu dan perhatian diberikan pada tanggung jawab pertama seorang perancang, yaitu menemukan dan mengembangkan solusi visual dimana tinggal di lingkungan sekitarnya. Tentu saja, produk tidak akan baik bagi siapa pun kecuali jikalau fungsinya berjalan dengan baik. Obyek harus mengungkapkan apa itu dan juga indah dengan sendirinya (Hannah, 2002).

Memahami bentuk dari garis, bidang dan volume membutuhkan latihan secara nyata, bukan dengan teori atau membaca buku saja, melainkan perlu praktek. Bentuk tiga dimensi terasa sulit dibayangkan jika hanya dengan menggunakan gambar atau sketsa. Melihat sebuah obyek tiga dimensi ataupun menyusun dan membuat obyek tiga dimensi harus beripkir dimensi koordinat $\mathrm{x}$ (panjang), $\mathrm{y}$ (lebar) dan z (tinggi).

Merancang sebuah bentuk tiga dimensi akan terasa mudah dan menjadi gampang dipahami jika membuat dan mengerjakan langsung dengan menggunakan material yang dapat dipegang sperti kertas, kawat dan benang. Garis terwakili oleh material kawat, benang, rotan, pipa, bidang (planar) terwakili oleh kertas, kardus, karton, papan. Volume bisa terwakili dengan benda-benda pejal bervolume atau susunan bidang planar.

\section{Tujuan dan Manfaat Penelitian}

\section{Tujuan Penelitian}

Penelitian ini bertujuan untuk memahami seberapa jauh kemampuan mahasiswa dan sekelompok orang dalam memahami proses mengenal bentuk dan volume yang merupakan bagian dari elemen-elemen desain. Bagaimana proses berlangsung dalam melakukan dan mengalami untuk melatih keterampilan desain dasar. Hasil dari penelitian ini akan dipakai untuk membuat bahan pertimbangan untuk membuat metode pengenalan perancangan bentuk serta pembuatan silabus maupun materi yang lebih mudah untuk dipahami dan dipraktekkan.

\section{Manfaat Penelitian}

Mengetahui kesulitan dan masalah yang ditemukan oleh mahasiswa maupun sasaran yang dituju tentang bagaimana dalam mengeskplorasi garis, bidang, dan volume untuk membuat sebuah struktur produk benda dengan ukuran besar seperti bangunan ataupun kecil seperti desain produk. Dengan menggunakan skala tertentu, latihan terus menerus adalah hal yang perlu dilakukan. Ketelitian setiap bentuk pada setiap material harus menjadi keseharian. Materi latihan yang tepat akan membantu belajar mengenal elemen desain dan prinsip-prinsip desain lebih mudah.

\section{Ruang Lingkup Penelitian}

Penelitian ini membahas masalah bagaimana mahasiswa desain atau seseorang yang ingin mempelajari dan berlatih mengembangkan kemampuan akan kesadaran bentuk dan ruang. Setiap individu mempunyai kemampuan membuat ruang dan bentuk yang berbeda. Kemampuan merancang bentuk dan ruang sangat diperlukan oleh calon perancang/ desainer baik desain ruang maupun bentuk produk. Beberapa latihan dasar mengelola bahan dan material dilakukan untuk membentuk prinsipprinsip dasar desain. 


\section{Studi Pustaka}

Tujuan mempelajari dasar-dasar seni rupa dan desain adalah melatih kepekaan artistik agar memiliki visi tinggi; melatih keterampilan teknis kesenirupaan; melatih pemahaman bahasa seni rupa; dan eskpresi diri (Sanyoto, 2010). Dalam Sanyoto (2010), unsur seni dan desain dalam merupa atau mendesain meliputi: bentuk, raut, ukuran, arah, tekstur, warna, value dan ruang.

Menurut Wong (1977), desain tiga dimensi serupa dengan desain dua dimensi, desain tiga dimensi juga bertujuan untuk menciptakan harmoni dan ketertiban visual, atau membangkitkan kegembiraan visual yang disengaja, kecuali yang berkaitan dengan dunia tiga dimensi. Ini lebih rumit daripada desain dua dimensi karena berbagai pandangan harus dipertimbangkan secara simultan dari sudut yang berbeda, dan banyak hubungan spasial yang kompleks tidak dapat dengan mudah divisualisasikan di atas kertas. Namun, ini lebih rumit daripada desain dua dimensi karena berkaitan dengan bentuk dan bahan nyata di ruang sebenarnya, sehingga semua masalah yang melibatkan representasi ilusi bentuk tiga dimensi di atas kertas (atau jenis permukaan datar) dapat dihindari.

Beberapa orang cenderung berpikir secara sculpturally, tetapi beberapa lainnya cenderung berpikir secara pictorially. Orang-orang ini mungkin memiliki beberapa kesulitan dalam desain tiga dimensi. Seringkali mereka begitu terlibat dengan pandangan frontal dari sebuah desain yang mereka anggap pandangan lain. Mereka mungkin menemukan struktur internal bentuk tiga dimensi selain pemahaman, atau mudah tertarik oleh warna dan tekstur permukaan saat volume dan ruang lebih penting.

Ada perbedaan sikap antara pemikiran dua dimensi dan pemikiran tiga dimensi. Perancang tiga dimensi harus mampu mevisualisasikan keseluruhan bentuk mental dan memutarnya secara mental ke segala arah, seolah-olah ada di tangannya. Dia seharusnya tidak membatasi citranya terhadap satu atau dua pandangan, tetapi harus benarbenar mengeksplorasi permainan kedalaman dan aliran ruang, dampak massa dan sifat bahan yang berbeda.

\section{Prosedur Penelitian}

Penelitian ini adalah merupakan penelitian partisipatoris. Peserta yang diteliti adalah mahasiswa desain produk, teknik arsitektur dan peserta awam yang mempunyai kegemaran merancang bentuk tiga dimensi.

Dengan temuan yang ada pada penelitian ini, metode memberikan latihan dan penyadaran akan bentuk dan ruang dapat diterapkan pada siswa dari tingkat dasar sampai perguruan tinggi, bahkan masyarakat awam. Tujuannya adalah agar sebagian orang yang tidak dapat menyampaikan ide dan gagasan secara dua dimensi dapat menggunakan bahan dan material yang dapat menggambarkan ide gagasan tiga dimensi tersebut. Dalam proses perancangan juga dikenal membuat study model yakni mencoba dengan material lain untuk mengetahui kelayakan bentuk dari sisi komposisi estetik. 


\section{Langkah-Langkah Penelitian}

\section{Metode Penelitian}

Sifat penelitian ini adalah berupa eksperimen, partisipatoris, pengamatan praktek dan literatur. Setelah melakukan eksperimen dan pengamatan praktek lalu dideskripsikan secara kualitatif. Penjelasan setiap karya yang dikerjakan oleh peserta pengamatan akan dibandingkan dengan literatur yang ada.

\section{Metode Pengumpulan Data Observasi Lapangan}

Melakukan pengamatan pada proses membuat karya tiga dimensi pada sekelompok siswa yang berkatian dengan kaidah-kaidah desain dasar tiga dimensi. Material yang digunakan menyesuaikan dengan karakter dan tujuan pada konsep dasar bentuk sesuai pada dasar-dasar desain tiga dimensi.

\section{Studi Literatur}

Studi literatur dengan cara mengumpulkan data berupa buku bacaan text maupun visual/ gambar dari buku fisik, e-book maupun internet. Kemudian, melakukan kajian teori khususnya mengenai dasar-dasar desain tiga dimensi.

\section{Analisis Data}

Metode analisis data dengan cara melakukan perbandingan antara praktek yang dilakukan para peserta di lapangan dengan teori yang ada dan pengalaman pada pengamatan yang pernah dilakukan sebelumnya. Sehingga, dapat ditemukan apa yang mendasari sebagian besar orang dalam membentuk rancangan tiga dimensi.

\section{Pembahasan}

Dalam studi visual, titik, garis, bidang dan volume adalah hal yang paling mendasar dari elemen-elemen visual. Volume dalam istilah konseptual digambarkan sebagai bidang bergerak ke arah selain arahnya yang inheren. Kemudian menjadi bentuk tiga dimensi yang berasal dari dan dilapisi dengan bidang planar, dengan posisi didalam ruang tiga dimensi (Wallschlaeger, 1992).

Memahami istilah membuat sketsa desain, khususnya yang mempunyai bentuk tiga dimensi adalah bagaiamana mengeksplorasi material yang dapat disentuh dan menghasilkan sebuah sketsa tiga dimensi.

Material yang digunakan untuk membuat sketsa ini terbagi menjadi :

1. Kawat sebagai garis yang mempunyai arah.

2. Kertas sebagai bidang planar.

3. Gypsum sebagai obyek yang bisa bervolume.

4. Struktur dus dari bahan kertas yang membentuk volume.

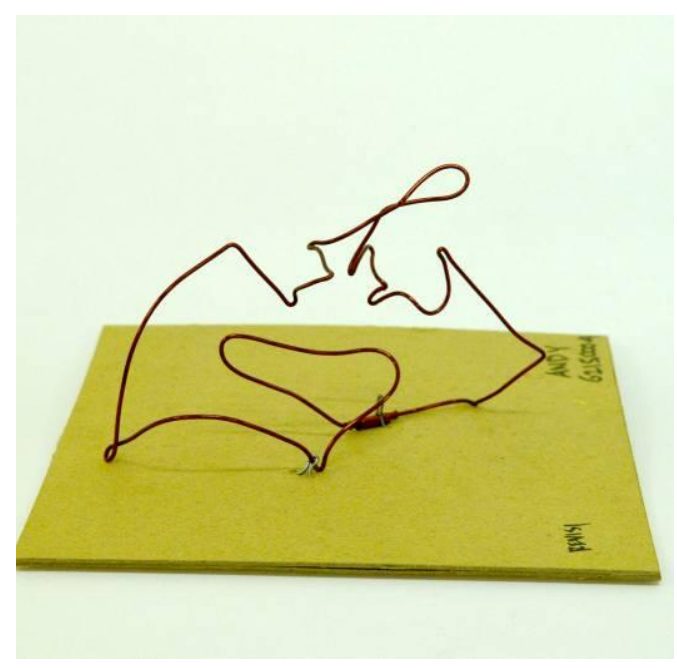

Gambar 1. Eksplorasi kawat sebagai garis Sumber: Dokumentasi Putro, 2015 
Pada Gambar 1, peserta diminta mewujudkan goresan tanda tangannya dari tulisan dengan pena pada kertas dengan menggunakan pensil atau pulpen. Selanjutnya dengan menggunakan kawat dengan cara dibentuk, dibengkokkan sesuai dengan bentuk goresan tanda tangan pada bidang dua dimensi di lembaran kertas. Berawal dari bentuk yang masih dua dimensi, kawat hanya berdimensi panjang kali lebar, diterjemahkan menjadi bentuk tiga dimensi pada sebidang kertas tebal sebagai alas. Hasil tersebut sangat membantu peserta untuk memahami unsur garis pada desain elementer menjadi sebuah volume, karena adanya dimensi bervolume dengan cara menarik beberapa titik pada bentuk tanda tangan dari kawat tersebut ke arah $\mathrm{x}, \mathrm{y}$ dan $\mathrm{z}$ (kiri, kanan, atas, bawah, depan dan belakang)

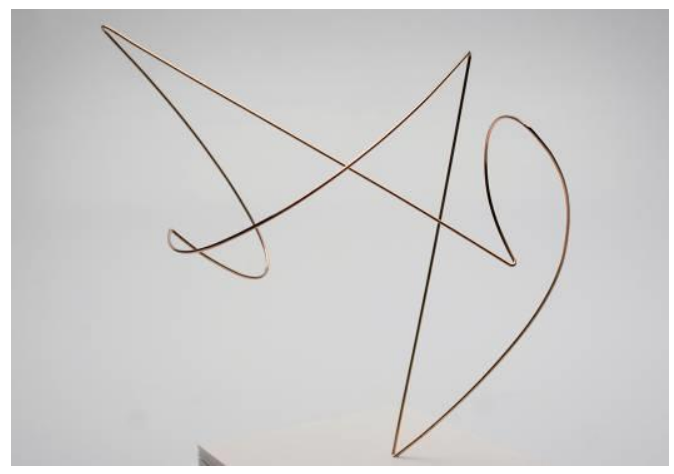

Gambar 2. Sketsa menggunakan kawat di atas bidang kombinasi lengkung dan tekuk sudut tajam

Sumber: Hannah, 2002

Selanjutanya pada Gambar 2, garis menggunakan kawat dikembangakan dari bentuk-bentuk lurus, lengkung, kombinasi lengkung dengan lurus, membentuk sudut tajam dan dan sudut tumpul atau kombinasi keduanya.

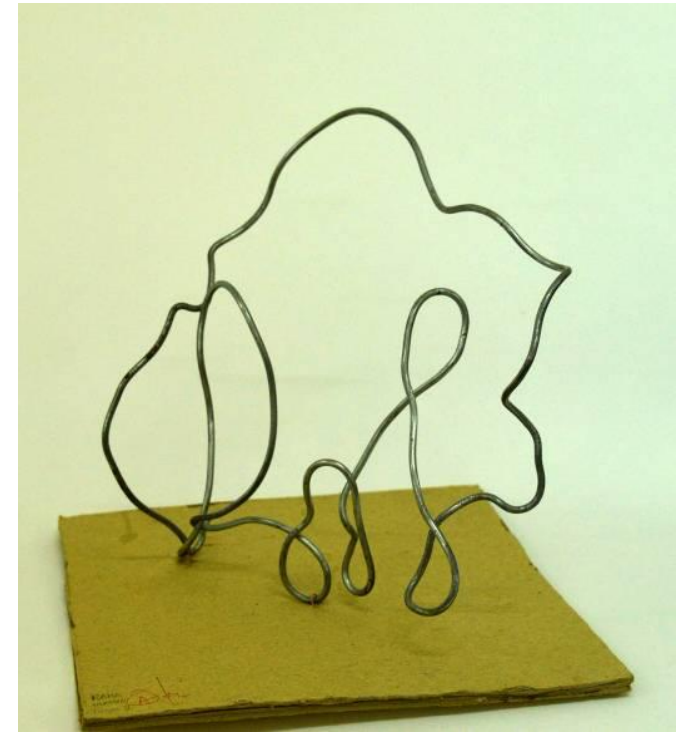

Gambar 3. Sketsa menggunakan kawat diatas bidang tanpa sudut tajam Sumber: Putro, 2016

Kawat sebagai garis yang dapat bergerak kearah sumbu $\mathrm{x}, \mathrm{y}, \mathrm{z}$ kemudian dapat diisi dengan garis yang lebih kecil sebagai isian yang berfungsi sebagai bidang dan membentuk volume. Garis yang lebih kecil dapat mengguanakan benang atau kawat kecil. Teknik sambungan secara teknis menggunakan ikatan maupun lem. Benang atau kawat kecil ini bisa dibayangkan sebagai material untuk konstruksi yang memiliki dimensi yang lebih kecil. Pada arsitektur dan konstruksi sipil biasanya berupa balok baja, ataupun gording dan balok kayu, kemudian isiannya berupa kaso dan reng. Pada desain produk seringkali digunakan sebagai kerangka atau konstruksi. Jika ini berupa dinding, ukuran material dari yang terbesar sampai terkecil sebagai konstruksi bisa disamakan dengan kawat dan benang pada studi model tersebut. 


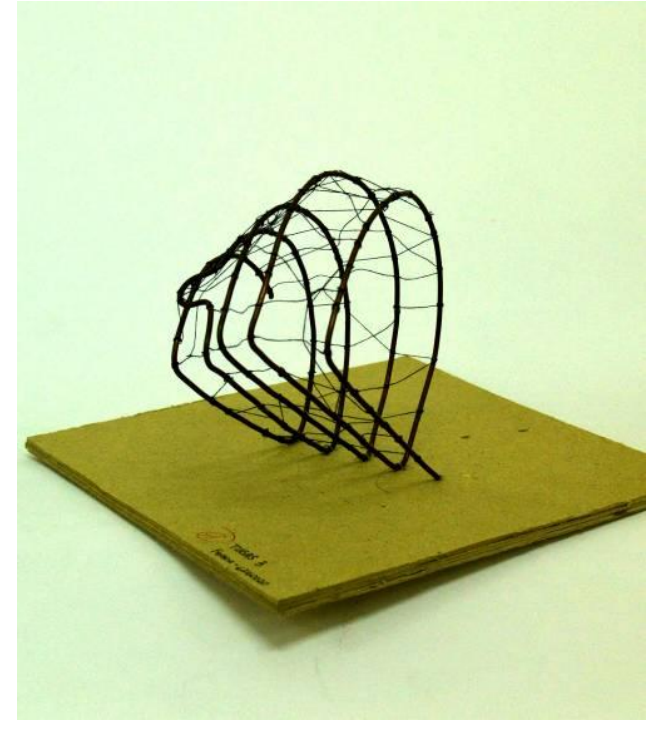

Gambar 4. Sketsa dengan kawat yang lebih kecil sebagai isian membentuk bidang dan volume

Sumber: Dokumentasi Putro, 2015

Setelah eksplorasi bebas menggunakan kawat besar dan kawat yang semakin mengecil, pengembangan bentuk berikutnya adalah dengan memberikan makna bentuk pada eksplorasi sebelumnya. Bentuk yang telah menyerupai sebuah figur sebagai latihan adaptasi bentuk alam. Binatang adalah bentuk yang paling mudah untuk ditiru karena setiap lekuknya, bentuk dan gesturnya mempunyai ciri khas masing-masing. Sebagai contoh antara anjing dan kambing, keduanya mempunyai kekhasan meskipun bentuknya hampir sama tetapi mempunyai kekhasan yang berbeda. Stilasi binatang menjadi ekperimen seperti berikut ini:

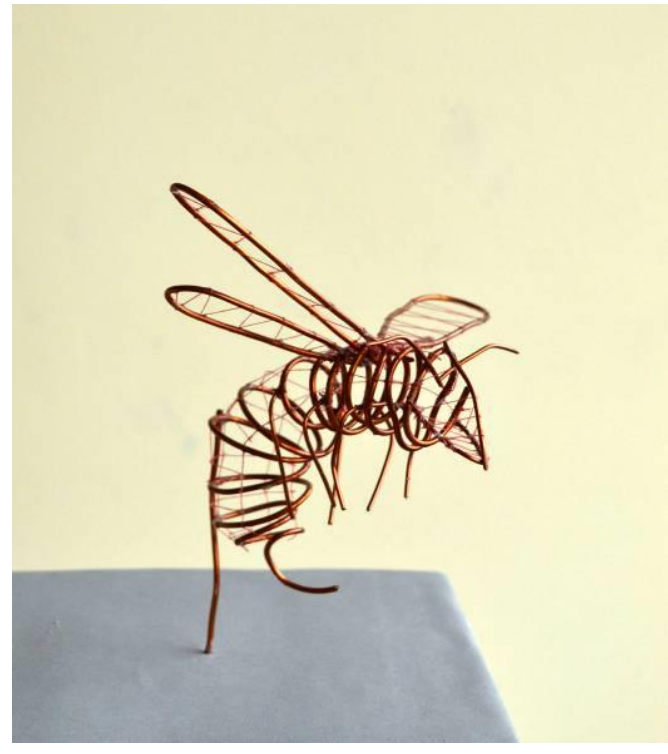

Gambar 5. Kawat sebagai media sketsa membantuk figur hewan (lebah) Sumber: Dokumentasi Putro, 2016

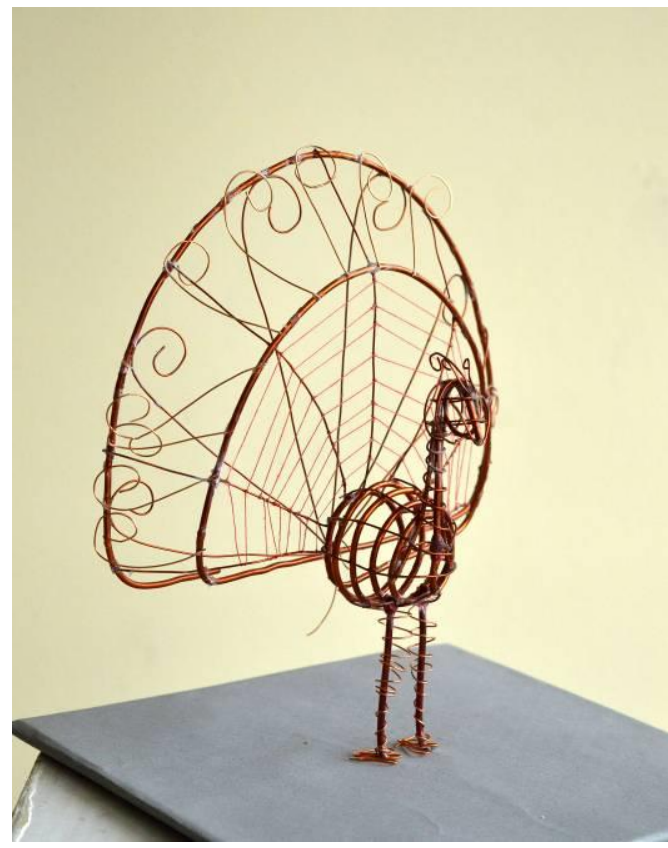

Gambar 6. Bentuk figur burung merak dari kombinasi kawat besar dan kecil Sumber: Dokumentasi Putro, 2016 


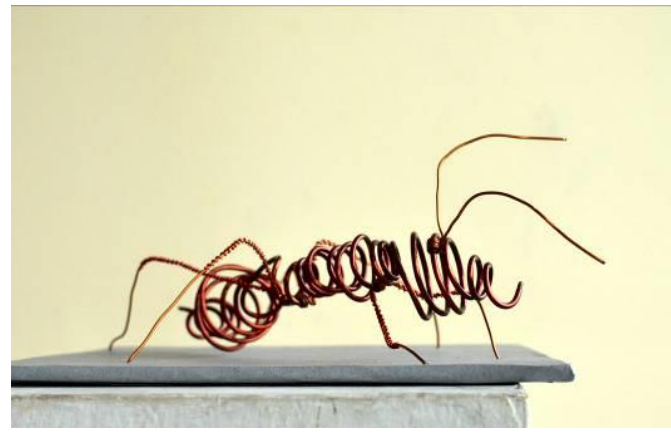

Gambar 7. Bentuk semut dari kombinasi kawat besar dan kecil

Sumber: Dokumentasi Putro, 2016

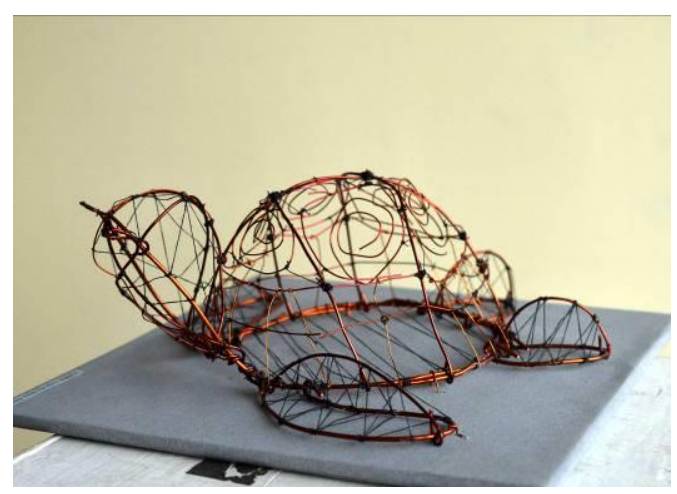

Gambar 8. Bentuk figur kura-kura dari kombinasi kawat besar dan kecil

Sumber: Dokumentasi Putro, 2016

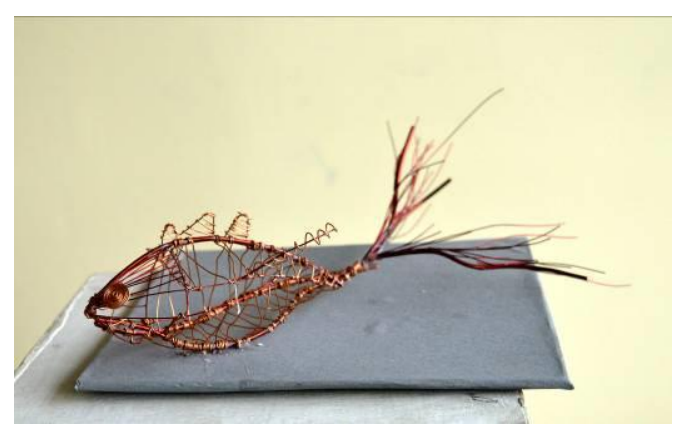

Gambar 9. Bentuk figur ikan dari kombinasi kawat besar dan kecil Sumber: Dokumentasi Putro, 2016

Dari 25 peserta yang membuat figure binatang dari kawat dengan dua ukuran dan berdiri diatas alas karton tebal ukuran $20 \times 20 \mathrm{~cm}$, hanya $60 \%$ peserta yang mampu mengkombinasikan antara kawat besar dan kecil dan tercapai karakter bentuk figurnya. Kesan volume yang terbentuk dari 2 ukuran kawat tercipta dengan melengkungkan, memutar, menekuk dan mengisi dengan kawat yang lebih kecil. Disini peserta telah dapat membayangakn bentuk bervolume meskipun hanya dengan menggunakan 'garis' berupa kawat.

Latihan membentuk dan bereksplorasi menggunakan bidang planar berupa kertas yang bertujuan untuk membentuk volume juga dilakukan. Dengan cara memotong kertas menjadi beberapa bagian dan melengkungkan tanpa menekuk, diharapkan peserta dapat menciptakan ruang dan volume, seperti pada gambar-gambar berikut ini:

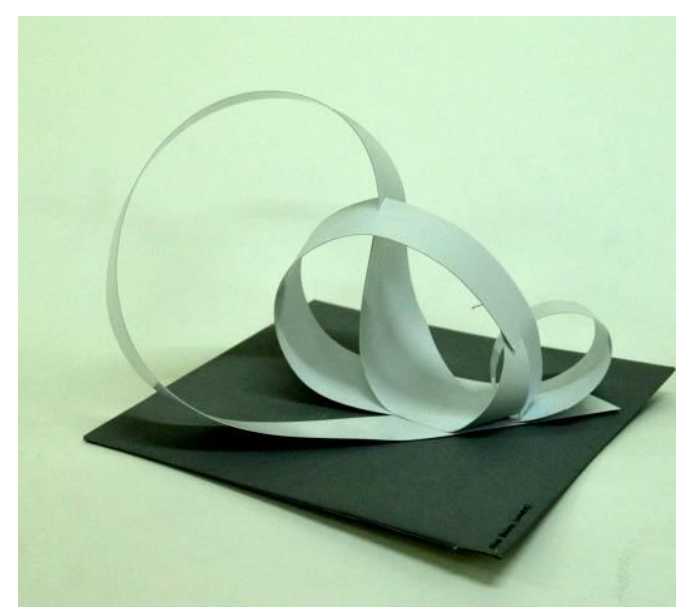

Gambar 10. Susunan bidang membentuk volume

Sumber: Dokumentasi Putro, 2016

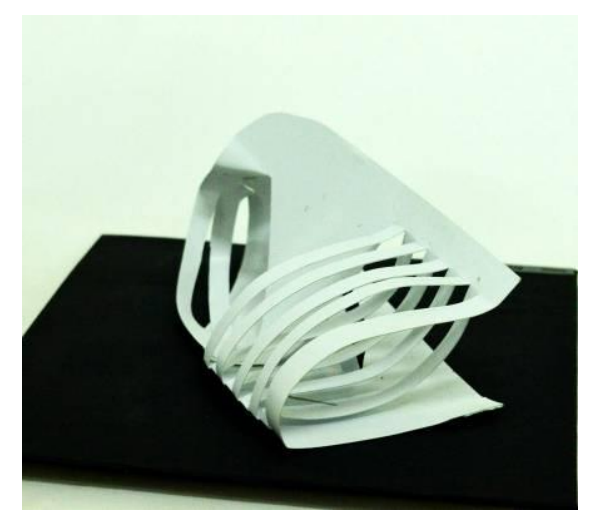

Gambar 11. Bentuk bebas dari bahan kertas

Sumber: Dokumentasi Putro, 2016 


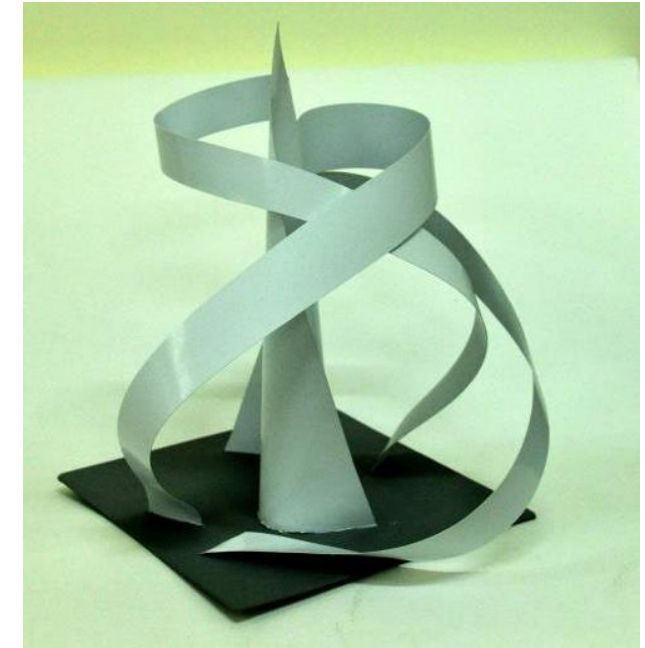

Gambar 12. Bentuk bebas dari bahan kertas

Sumber: Dokumentasi Putro, 2016

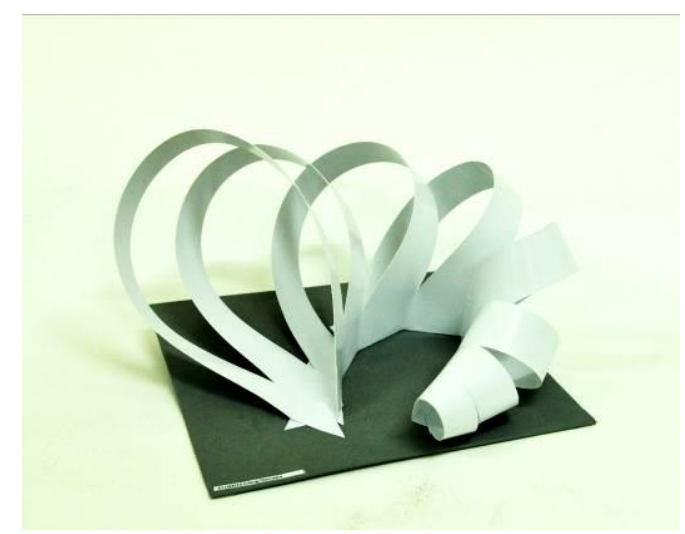

Gambar 13. Kertas lembaran tanpa ditekuk membentuk volume berongga Sumber: Dokumentasi Putro, 2017

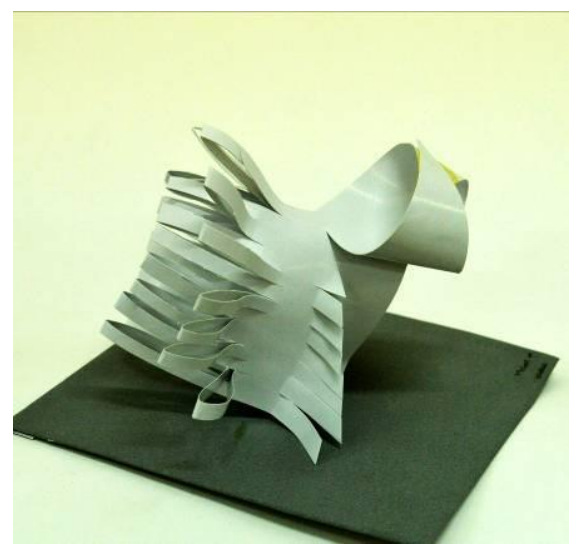

Gambar 14. Kertas sebagai bidang, dipotong, ditekuk, disambung membentuk volume berongga

Sumber: Dokumentasi Putro, 2015
Pada latihan membuat sebuah bangun bervolume pejal atau padat berisi dilakukan dengan menggunakan box kertas. Box kertas dapat diperoleh dari bekas kemasan produk berupa kertas atau karton, bentuk lain seperti tabung dan bola dapat diperoleh dengan menggunakan barang yang ada disekitarnya. Dengan cara menyambung, memotong, mengiris, melubangi, peserta bisa berlatih menyusun sebuah bentuk bervolume padat dengan memperhatikan prinsipprinsip desain.

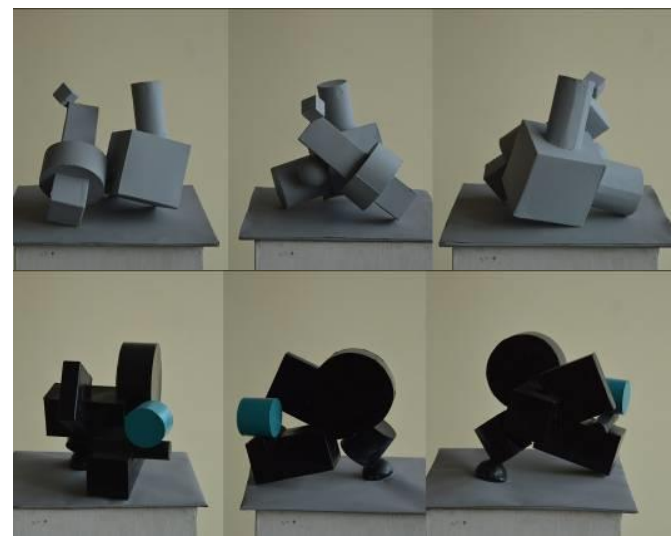

Gambar 15. Bentuk bangun dengan menyusun dari bahan box kemasan dan dicat

Sumber: Dokumentasi Putro, 2016

Pengamatan pada latihan menyusun box, tabung, dan bola dari kemasan mempunyai tingkat kesulitan menyambung dan memotong. Jika ada beberapa bentuk yang tidak tersedia dari kemasan peserta membuat sendiri bentuk box tersebut dengan kertas karton. Finishing cat diperlukan untuk bisa melihat karya akhir dengan obyektif dan mempunyai value warna yang sama, sehingga memudahkan dalam menilai komposisi tersebut sesuai dengan prinsip-prinsip desain.

Pada eksperimen membentuk benda pejal dengan tanah liat dan gypsum beberapa peserta mengalami kesulitan saat membuat sebuah bentuk bulat 
telur dari bahan clay. Dari model clay dicetak menjadi gypsum.

Kesulitan ini membuktikan bahwa untuk membuat bentuk sesederhana bulat telur membutuhkan ketelitian dan memperhatikan proporsi ukuran. Sangat berbeda sekali saat peserta hanya menggambar dengan pensil pada kertas. Mempraktekkan pada media berupa tanah liat (clay) ataupun gypsum memerlukan perhatian dan konsentrasi dan pengukuran yang terus-menerus pada proses tersebut.

Beberapa peserta merasa mampu dan bisa mewujudkannya ketika menggambar dengan pensil, tetapi pada prakteknya ada yang melakukan kesalahan sehingga bentuknya tidak sempurna, seperti pada gambar berikut ini.

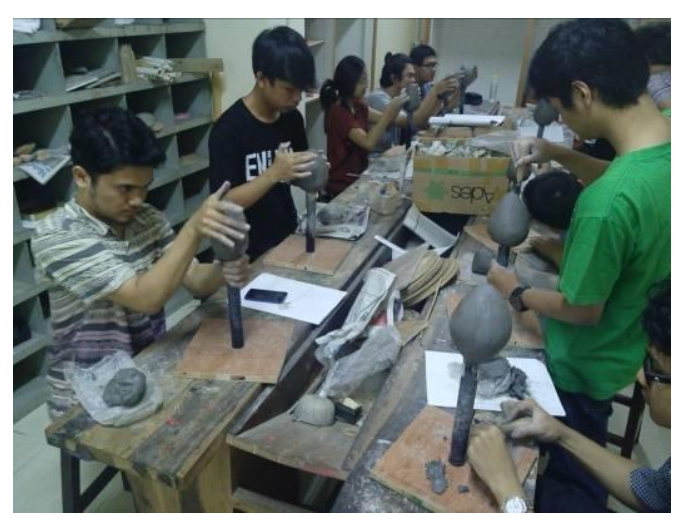

Gambar 16. Peserta membuat bentuk bulat telur dari bahan tanah liat

Sumber: Dokumentasi Putro, 2015

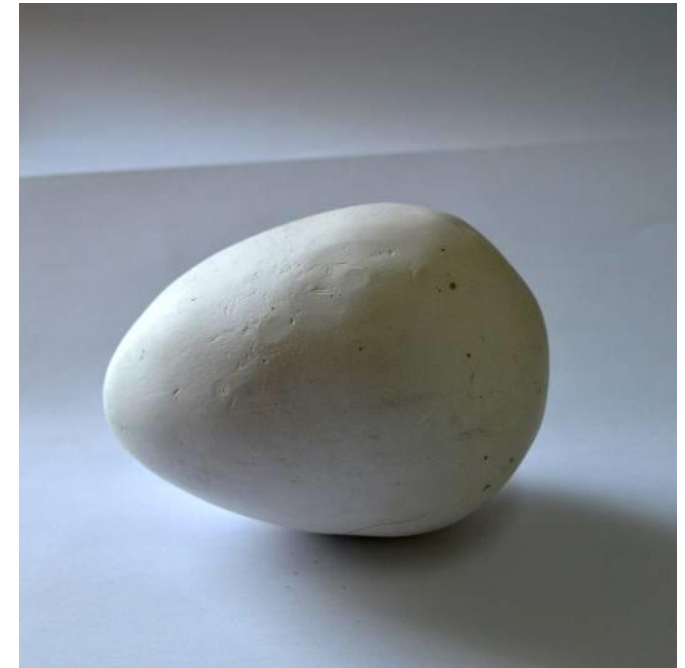

Gambar 17. Bentuk bulat telur dari bahan gypsum hasil karya peserta

Sumber: Dokumentasi Putro, 2015

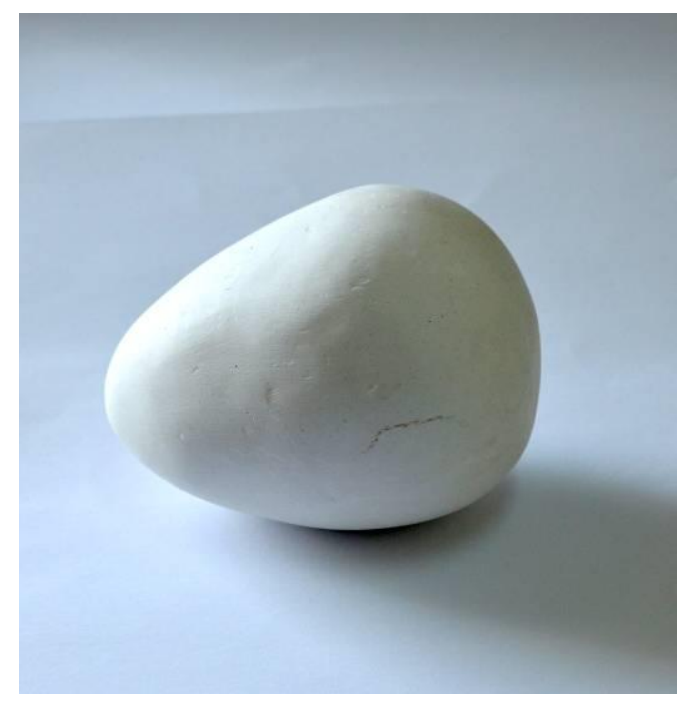

Gambar 18. Bentuk bulat telur dari bahan gypsum hasil karya peserta

Sumber: Dokumentasi Putro, 2015

Beberapa bentuk buat telur tidak menyerupai telur, tetapi terjadi distorsi menjadi lebih panjang atau terlalu bulat. Bahkan ada beberapa bentuk yang tidak berhasil dibuat karena kesalahan dalam perlakuan bahan material pembentuknya (gypsum) seperti terlihat pada gambar 20 . 


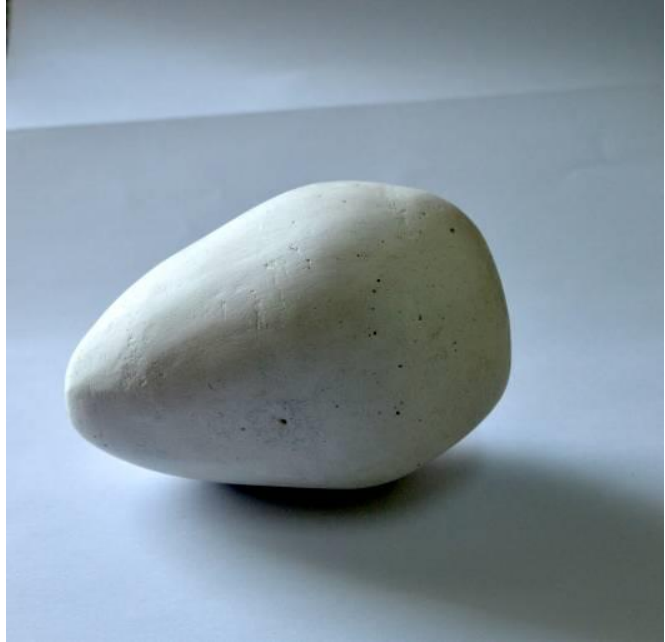

Gambar 19. Bentuk bulat telur dari bahan gypsum yang kurang sempurna Sumber: Dokumentasi Putro, 2015

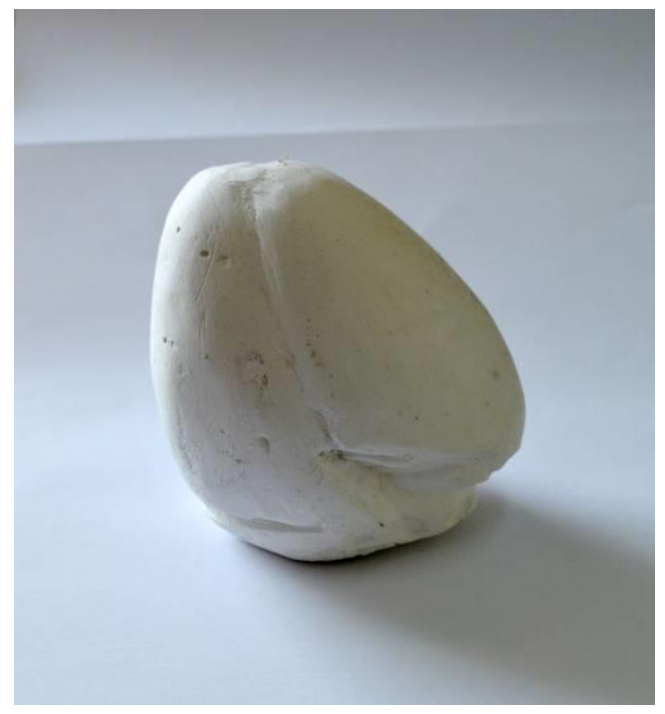

Gambar 20. Bentuk bulat telur dari bahan gypsum yang tidak sempurna Sumber: Dokumentasi Putro, 2015

Eksplorasi berikutnya adalah bentuk kombinasi dari beberapa bentuk lengkung bulat atau cembung tanpa sudut tajam, melatih peserta untuk menggabungkan bentuk dasar bulat, bulat telur dan bentuk-bentuk yang disusun dan dipanjangkan atau dipendekkan seperti pada gambar 21 .

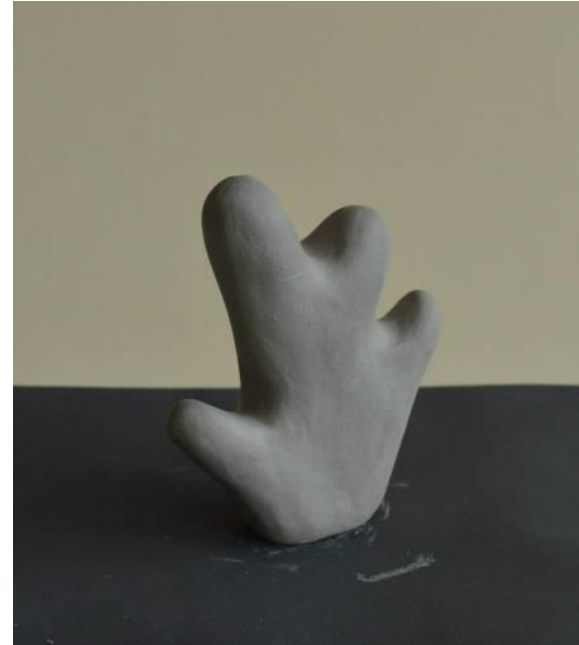

Gambar 21. Eksplorasi bebas dari bentuk dasar cembung tak bersudut tajam Sumber: Dokumentasi Putro, 2016

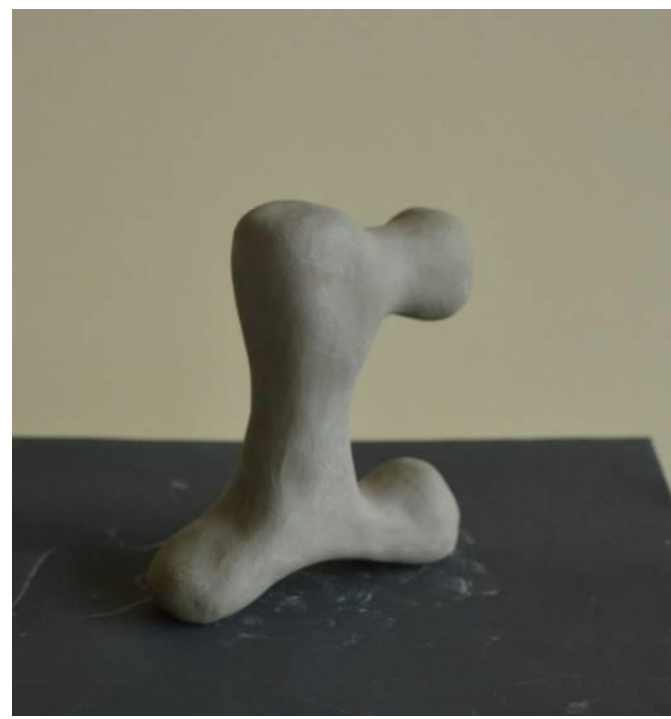

Gambar 22. Eksplorasi bebas dari bentuk dasar cembung tak bersudut tajam Sumber: Dokumentasi Putro, 2016 


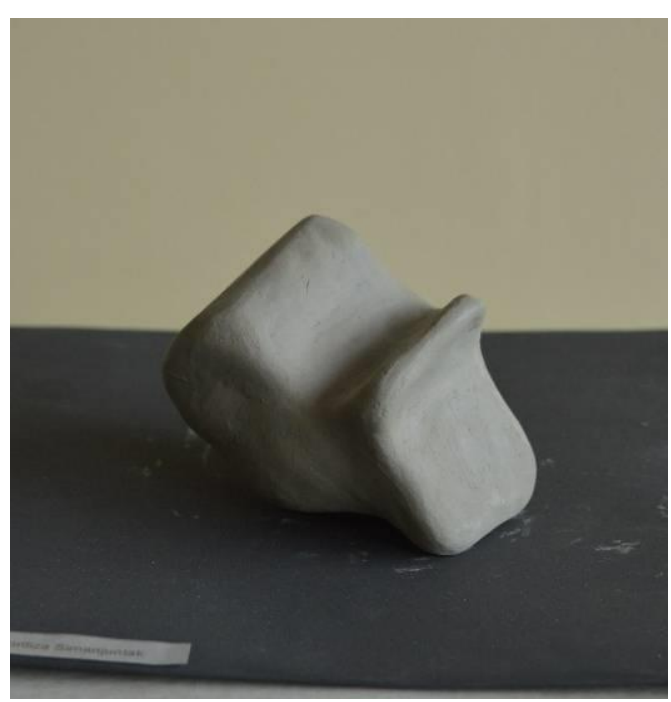

Gambar 23. Eksplorasi bebas dari bentuk dasar lengkung dan garis lurus dan bersudut sedikit tajam

Sumber: Dokumentasi Putro, 2016

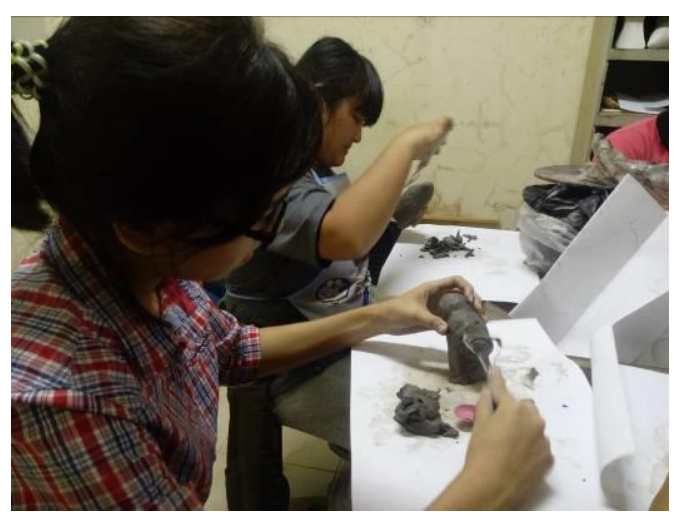

Gambar 24. Peserta membuat bentuk bebas dari unsur bentuk cembung

Sumber: Dokumentasi Putro, 2016

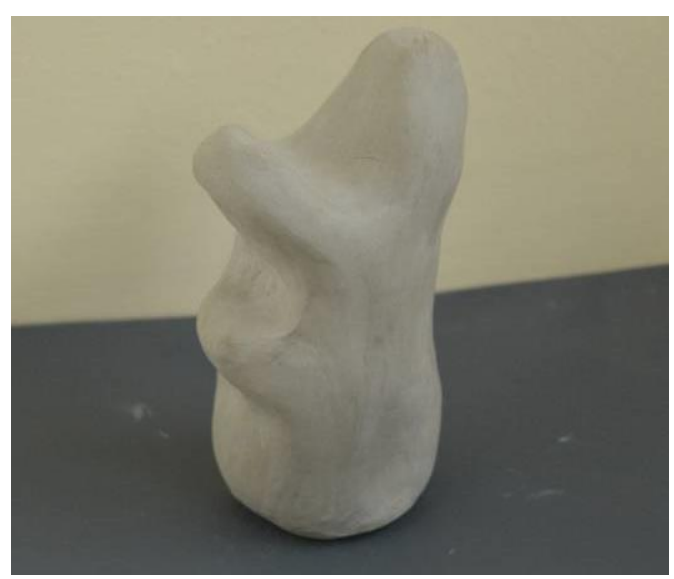

Gambar 25. Eksplorasi bebas dari bentuk dasar cembung dan bersudut sedikit tajam Sumber: Dokumentasi Putro, 2016
Sebagai contoh karya 3 dimensi yang diimplementasikan pada sebuah tempat atau daerah baik arsitektur maupun kawasan dari sisi keindahan, salah satunya adalah karya patung. Kota Chicago, USA, dengan serius mencanangankan motto: "City in a Garden” sehingga banyak sekali karya bentuk 3 dimensi berupa patung maupun gedung yang indah dan estetis.

Bentuk bervolume dirancang dengan pasti tidak lepas dari prinsip-prinsip desain. Karya-karya ini banyak dikerjakan oleh para seniman patung dan arsitek. Salah satu area tersebut adalah di kompleks Millenium Park. Disana terdapat sebuah ikon/landmark yang cukup dikenal yaitu "Cloud Gate" atau "The Bean"

"Cloud Gate" karya Anish Kapoor hanyalah salah satu dari banyak karya seni luar ruangan di Millennium Park, namun tidak diragukan lagi kerumunan oleh orang banyak. Dulu diresmikan pada tahun 2004 di Plaza SBC dan dalam waktu singkat ini menjadi salah satu karya seni kontemporer yang paling sukses di Amerika. Menurut Kapoor, seorang seniman kelahiran India yang tinggal di Inggris Raya, potongan itu sebenarnya terinspirasi oleh merkuri cair. Patung setinggi 33 kaki (10 meter), dan panjang 66 kaki (20,1 meter) itu adalah salah satu yang terbesar di dunia yang terdiri dari 168 plat stainless steel, masing-masing memiliki berat sekitar 1.700 pon (771,1 kg) (Cremin, 2006). 


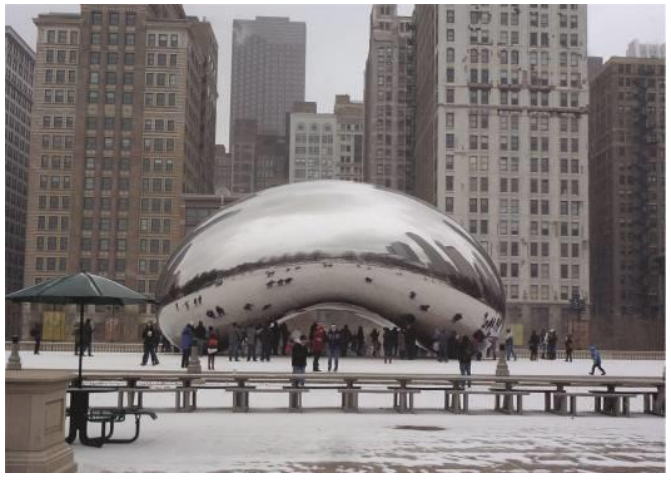

Gambar 26. Karya Anish Kapoor

Sumber: Dokumentasi Putro, 2013

Selain itu karya arsitektur dengan bentuk komposisi dinamis dan kesan retak, geometrik tajam sangat terlihat pada karya arsitek Daniel Libeskind, seorang arsitek, seniman, profesor dan pemenang untuk rekonstruksi World Trade Centre di Manhattan, New York, USA pada tahun 2003. (http://en.wikipedia.org)

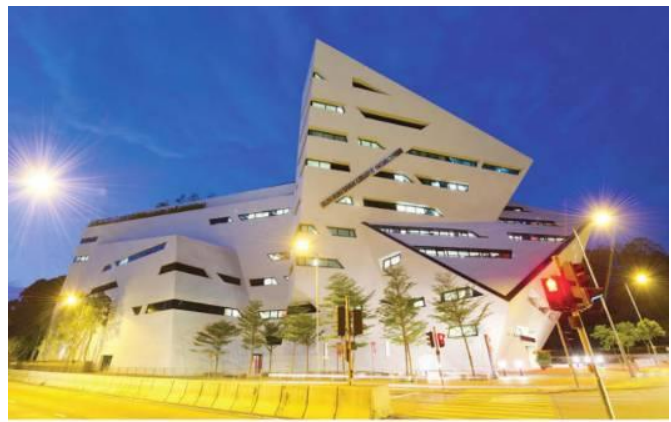

Gambar 27. Run Run Shaw Creative Media Centre, City University, Hong Kong. Sumber: Coulson, 2015

Bentuk geometris bersudut tajam seperti pada Gambar 27 karya Daniel Libeskind adalah salah satu bentuk yang merupakan eksplorasi dasar desain, ditinjau dari sisi visual dengan bentuk dasar planar bersudut.

\section{Kesimpulan}

Eksplorasi bidang, bentuk dan volume mencapai nilai visual estetis yang sesuai dengan prinsip-prinsip dasar desain visual dan juga konsep yang menyertainya. Hal ini merupakan hal yang harus dilakukan untuk membiasakan berkreasi bebas.

Melakukan latihan terus-menerus menggunakan media yang dapat dipegang dengan tangan langsung seperti kawat, kertas, karton, clay, gypsum; memegang dengan tangan langsung (hands on) pada obyek rancangan atau model bertujuan untuk melatih mahasiswa atau peserta belajar untuk menjaga kerapian, ketelitian memahami detail adalah mutlak saat nanti menjadi seorang perancang professional. Hal tersebut mendasari perancang untuk bebas mengekplorasi garis, bidang, bentuk dan volume dengan bebas tanpa merasa akan kesulitan dalam perwujudannya nanti. Kesulitan perwujudan pada material sesungguhnya akan dikolaborasikan dengan bidang keahlian dan bidang ilmu lain, apakah bisa dicapai atau tidak, tentunya dengan kompromi secukupnya.

Memahami karakter material seperti kawat, kertas, karton, kain, tanah liat, gypsum, benang adalah sebuah proses yang harus dilewati supaya kenal bagaimana memperlakukan material tersebut agar menjadi sebuah susunan bentuk yang estetik sesuai dengan prinsip-prinsip dasar tata rupa khususnya dalam membentuk sebuah ruang atau volume.

\section{Daftar Pustaka}

Coulson, J., Roberts, P., Taylor, I. (2015). University trends: Contemporary campus design. London: Routledge.

Cremin, D. H. (2006). Chicago, a pictorial celebration. New York: Sterling Publishing Company, Inc. 
Hannah, G. G. (2002). Elements of design: Rowena Reed Kostellow and the structure of visual relationships. New York: Princeton Architectural Press.

Sanyoto, S. E. (2010). Nirmana; Elemen-elemen seni dan desain. Yogyakarta: Jalasutra.

Wallschlaeger, C., Busic-Snyder, C. (1992). Basic visual concepts and principles: For artists, architects and designers. New York: McGraw-Hill Book Company.

Wong, W. (1977). Principles of threedimensional design. New York: Van Nostrand Reinhold. 